\title{
Impact of Groundwater Discharges on Marine Water Quality in Doha, Qatar
}

\author{
Magda M. Abd-Elaty El-Magharaby*, Samia Galal*, Ghazy Abdel kreim*, Khaled El- \\ Emady**
}

\begin{abstract}
Qatar is classified, according to its geographical location and climate, as a hot subtropical desert. Qatar's average annual rainfall is less than $130 \mathrm{~mm} /$ year (5 in). Doha, the capital of State of Qatar, is served by a collection system of groundwater and storm water which finally is disposed off into the marine water through three outfalls. In the future, another four proposed outfalls will be operating. This study aimed at assessing the impact of groundwater discharge on the receiving marine water quality. Water Samples were collected from the outfalls it themselves, Sea water from different sites around these outfalls at different distances, sea water Samples from different sites around the proposed points at different distances, and offshore samples as reference. Samples were collected during year 2007 and were analyzed physicochemically and microbiologically. Physicochemical characterization of the discharges showed that all measured parameters were complied with the environmental limits of both Qatar and GCC laws except turbidity and total suspended solids. The values of total and fecal coliform were higher than the permissible limits for Qatar and GCC environmental laws. The Physico-chemical characterization of the sea water samples collected from different sites around the discharged points recorded higher total suspended solids than the permissible limits stated by the Qatari law while the other parameters were complying with the law. Total suspended solids were higher than the permissible limits in all marine water samples while samples around the discharges points were the highest. The excess of some parameters reported by the study is due to the state urbanization and constructions activities in general. An integrated management plan must be carried out by all governmental and non-governmental authorities to protect the groundwater and avoid the deterioration of marine water quality.
\end{abstract}

\section{INTRODUCTION}

The GCC countries are characterized

by a harsh desert environment devoid of

rivers and lakes. The water resources

consist of limited quantities of runoff

resulting from flash floods, groundwater

in the alluvial aquifers, and extensive

groundwater reserves in deep sedimentary formations. Some of these countries also

rely on non-conventional water sources

such as desalinization of sea and brackish

water and limited use of renovated wastewater. Groundwater in the shallow aquifers is the only renewable water source in some countries. Oil pollution in the

\footnotetext{
${ }^{*}$ High Institute of Public Health, Alexandria University.

** Public Works Authority, Qatar
} 
region is very pronounced.(1)

Qatar is classified, according to its geographical location and climate, as a hot subtropical desert. (2) From May to October the Qatari climate is extremely hot, commonly reaching as high as $50^{\circ} \mathrm{C}$ $\left(120^{\circ} \mathrm{F}\right)$, with high humidity near the coastline. In the other months the weather is generally moderate and pleasant, with daily temperatures averaging $17^{\circ} \mathrm{C}\left(63^{\circ} \mathrm{F}\right)$. Rainfall, which occurs only in the winter, is very slight: Qatar's average annual rainfall is less than $130 \mathrm{~mm} /$ year (5 in). (3) Sometimes, heavy storms that often flood the small ravines and the usually dry Wadies. ${ }^{(4)}$

The country has no rivers or lakes, and besides the rainfall received, the primary source of fresh water is the groundwater. Surface water is very limited; only after a good winter rainfall, water may be seen in depressions, Wadies, and runnels for a short time.(2) The scarcity of rainfall and the limited underground water, most of which has such a high mineral content that it is unsuitable for drinking or irrigation has restricted the population and the extent of agricultural and industrial development of the country could support until desalination projects began. ${ }^{(4)}$

Following rainfall events, runoff flows overland and picks up materials including but not limited to trash, debris, sediments, and organic pollutants. The runoff can often contain pollutants in quantities that will affect water quality. Runoff can carry a variety of pollutants that are associated with a specific land use. These materials can remain in solution or attach to sediment and will eventually be deposited in the lowest part of the landscape or discharged to creeks, rivers, lakes, sea, and wetlands. (5)

Increased pollutant loadings and discharges are still another impact of urban storm water runoff from impervious surface areas. Pollutants associated with urban areas are specific to the type and intensity 
of the land use. Some examples of pollutants associated with urban land uses include sediments, nutrients, oxygen demanding substances, heavy metals, oils and grease, hydrocarbons, and bacteria. Runoff from commercial land uses such as shopping centers, business districts, office parks, and parking lots or garages may contain high hydrocarbon loadings and metal concentrations. Pollutant loadings from these types of land uses can be a significant pollutant source in storm water runoff and can be attributed to heavy traffic volumes and large impervious surface areas. Gas stations are one type of land use that is often designated as a commercial land use and are subject to the same controls as shopping centers and office parks. However, gas stations may generate higher concentrations of heavy metals, hydrocarbons, and other automobile-related pollutants due to dayto-day activities associated with the industry and the volume of clientele that use the facilities. There is also a higher probability for spills to occur at these facilities because of human error.

Sediment is the most common pollutant associated with storm water runoff from construction sites. However, there are several other pollutants associated with construction activities. Some of these pollutants include, but are not limited to, solid wastes, nutrients, pesticides, petroleum products, and chemicals associated with construction activities. ${ }^{(5)}$

The urban areas in Qatar are experiencing groundwater aquifer contamination from many sources. Wastewater network can practice leaks reaching the surface soils, Septic tanks with soak bottoms which used in areas not served with wastewater collection systems. Road drainage and soak ways are another source of groundwater charge and pollution and Illegal discharges to the groundwater network from tankers emptying septic tanks. Uncontrolled dewatering activities 
after issuance of permits for new reference. Samples were collected during construction site preparations.

year 2007. Samples were analyzed

Doha, the capital of state of Qatar physicochemically and microbiologically is served by a collection system of groundwater and storm water which are finally disposed off into the marine water through three outfall. In the future, another fourth proposed outfall will be operating.

This study aimed at assessing: 1-the impact of the discharged groundwater and storm water on the receiving sea water, 2the water quality in compliance with the environmental laws in the region and with the references sites in Qatar marine water.

\section{MATERIAL AND METHODS}

Samples plan as follows:

Water samples were collected from the outfalls themselves through the pump stations. sea water samples were collected from different sites around these outfalls at different distances. Sea water samples were collected from different sites around the proposed points at different distances. Offshore samples were collected as according to standard methods $(\mathrm{SM})^{(6)}$, USEPA methods( ${ }^{(7)}$, UNEP(8) and chemical and biological methods for sea water analysis( $^{(9)}$ as presented in table (1). All analyses were done at the Environmental Studies Centre, Qatar University.

\section{RESULTS AND DISCUSION}

\section{Characterization of outfalls discharges:}

Table (2) presented the physicochemical characterization of the discharges; it was noticed that all measured parameters were complied with the environmental limits of both Qatar and CGC laws except turbidity, total suspended, and dissolved solids. The mean values are 94.3 NTU, $2475.2 \mathrm{ppm}$, and $19653 \mathrm{ppm}$, respectively. Turbidity is surrogate of suspended solids. The high values of solids may be due to the seepage from the septic tanks, erosion from soils, and antecedent long dry period. Also the solids may be due to the construction 
activities which increase the precipitation load.

Toxic and persistent chemicals as presented in table (2) recorded phenol mean value of $0.008 \mathrm{ppb}$ and $\mathrm{PAHs} 0.0006$ ppm which comply with the permissible limits for both Qatar and GCC laws. On the other hand, TPHs and PCBs detected mean values of $9.16 \mathrm{ppb}$ and $0.01 \mathrm{ppb}$, respectively. No limits for both were reported by the laws.

As presented in table (3), heavy metals were far below the permissible limits of the Qatar and GCC environmental laws. These are due to that this groundwater does not contain industrial sources.

Attributed to the indicator organisms of fecal pollution, the total coliform mean value was $6.9 \mathrm{E}+04 \mathrm{MPN} / 100 \mathrm{ml}$. and fecal coliform mean value was $2.7 \quad \mathrm{E}+04$ MPN/100 $\mathrm{ml}$. On the other hand, fecal streptococci mean value was $9.0 \mathrm{E}+10$ MPN/100 ml. As shown by figure (1), the values of total and fecal coliform were higher than the permissible limits for Qatar and GCC environmental laws. These results were the guide for the presence of seepage from the septic tanks, illegal tankers empting and sewers system corrosion. Other sources for coliform are the storm water runoff. No limit was recorded for fecal streptococci by both laws. Fecal streptococci have not been widely used as fecal pollution indicators. The use of the fecal streptococci is to assess the relative contributions of animal and human fecal sources to observed levels of microbiological contamination in water systems. ${ }^{(10)}$

\section{Characterization of marine water:}

1- Around the discharge

\section{Physico-chemical characterization:}

Waterways and receiving waters near urban and suburban areas are often adversely affected by urban storm water runoff. Urban runoff was the leading source of pollutants causing water quality impairment. Adverse impacts on receiving 
waters associated with storm water around the discharged points recorded discharges have been discussed in terms that: Total suspended solids were higher of three general classes. ${ }^{(11)}$ These are: - than the permissible limits stated by the Short-term changes in water quality during Qatari law while the other parameters and after storm events including temporary increases in the concentration of one or more pollutants, toxics or bacteria levels. • Long-term water quality impacts caused by the cumulative effects associated with repeated storm water discharges from a number of sources. - Physical impacts due to erosion, scour, and deposition associated with increased frequency and volume of runoff that alters aquatic habitat.

Pollutants associated with urban runoff potentially harmful to receiving waters fall into the categories listed below:(11)

- Solids • Oxygen-demanding substances • Nitrogen and phosphorus

- Pathogens - Petroleum hydrocarbons • Metals - Synthetic organics.

As represented in table (4), the Physicochemical characterization of the sea water samples collected from different sites comply with the law. Attributed to the high value of suspended solids, $79.5 \mathrm{ppm}$, it can lead to alterations of the physical, chemical, and biological properties of the water-body. Physical alterations caused by SS include reduced penetration of light and temperature changes. ${ }^{(12)}$

Chemical alterations caused by SS include the release of contaminants, such as heavy metals and pesticides, and nutrients such as phosphorus, into the water body from adsorption sites on the sediment. (12) High suspended solids attributed to the discharges which already contain high values. In road/highway runoff, suspended solid (SS) is considered as one of the major pollutant since many micro-pollutants are attached to $i^{(13,14)}$. The pollutants' accumulating behavior depends on SS particle sizes. (15) 
Toxic and persistent chemicals:

Phenol is commonly found in phenolic resins used in the plywood, construction, automotive and appliance industries. Some phenolic compounds occur in a variety of residential and commercial cleaning products such as detergents, shampoo, and surface cleaners. At high concentrations, phenol is toxic to aquatic organisms. ${ }^{(16)}$ The present results detected phenol mean value of 9.79 ppb, as presented in table (4), which uncomplies with the limits. Sewage and storm-water are the likely sources of such chemicals in the marine environment.(17) The environmental half-lives of phenols are short, rarely as long as month. Some are photo-degraded, especially in air. Once a discharge ceases, environmental levels will drop rapidly due to the bacterial breakdown. The existence of high level in fish tissues indicates chronic or current exposure. At extremely low phenol values, there are two effects apparent in phenol- contaminated waters: toxicity to aquatic life and the generation of an unpleasant taste in fish and shellfish. ${ }^{(18)}$

Polychlorinated biphenyls (PCBs) are one of the 12 POPs chemicals. PCBs comprise over 200 individual compounds of varying toxicity. POPs are known to have toxicological impact on wildlife and humans. ${ }^{(16)} \quad$ The results reported, as presented in table (4), mean value of PCBs was $30.4 \mathrm{ppb}$. No limits recorded in Qatari law for it. It is known that PCBs contaminants are generally bound to the soil and sediments and may be released to the water slowly over a long time. The detection of PCBs in marine water reflecting impact of past sewage discharges and urban runoff. ${ }^{(16)}$

Polycyclic aromatic hydrocarbons are a group of chemicals derived primarily from the incomplete burning of organics; some PAHs are recognized as carcinogenic (e.g., benzo(a)pyrene).(18) The present study detected that PAHs mean value was 22.2 
ppb as represented in table (4). There are many traffic- related sources of PAHs which include vehicle exhaust, lubricating oils, gasoline, diesel fuel, and tyre particles (19-21). Also the contamination of water and soil by PAHs along highways reported by other studies(22, 23).

Other sources of PAHs in theenvironment are diverse, including cigarette smoke, grilling of meat, coal burning, and hazardous waste sites. ${ }^{(15)}$ Micro-pollutants such as PAHs and heavy metals are widely distributed in dust, soils, and sediments, and are found in roof and road runoff(24). Hoffman et al.,(25) estimated that $36 \%$ of environmental $\mathrm{PAH}$ input was due to urban runoff; for the higher molecular weight PAHs, the figure was $71 \%$. Urban runoff has been recognized as an important $\mathrm{PAH}$ pathway to water environments and aquatic ecosystems. Hence, effective control strategies for PAHs in urban runoff are required to assure human and ecosystem safety. Krein and Schorer(22) reported higher molecular weight PAHs attached to coarse particle fraction.

Pollution of sea by petroleum hydrocarbons land based discharges, and atmospheric and natural inputs. (26) Results reveled that TPHs mean value was 2.7 ppb as presented in table (4). It complies with the limits while its maximum value of $18.9 \mathrm{ppb}$ does not comply. The concentration of hydrocarbons and metals related to the land use, commercial, roads, and industrial land uses had higher concentrations of both metals and PAHs than residential land uses. ${ }^{(27)}$ Though a considerable fraction of petroleum hydrocarbons entering the marine environment is removed by evaporation, a portion gets distributed in water, accumulated in sediment and transferred to biota. The input of petroleum hydrocarbons to the marine environment from different sources as follows: $65.2 \%$ is discharged through municipal and industrial waste, 
urban and river runoffs, oceanic dumping and atmospheric fallout; $26.2 \%$ derives from discharges during transportation, dry docking tanker accidents blasting,...,etc.; and remaining $8.5 \%$ comes from fixed installations like coastal refineries, offshore production facilities, marine terminals,...,etc. ${ }^{(26)}$ the concentration of TPHs is often high in the bottom water particularly at inshore shallow areas. The sediment particles rich in TPHs dispersed in the water column by strong tidal currents sweeping these zones could contribute to dissolve TPHs. The concentrations of TPHs in the coastal waters of India vary widely and values in the range $0-139 \mathrm{ppb}^{(28,29)} \quad$ Chouksey et al., (26) reported TPHs in water off BasseinMumbai (India) varies widely (2.9-39 ppb).

\section{Metals}

Results indicated that, 4 metals were detected in higher values than the permissible limits. These are Iron with mean value of $134.7 \mathrm{ppb}$, Copper with mean value of $85.9 \mathrm{ppb}$, Cadmium with mean value of $318.4, \mathrm{ppb}$ and lead with mean value of $23.3 \mathrm{ppb}$ as presented in table (5).

In Qatar, there are many projects for road construction and maintenance which causes various types of environmental concerns. Asphalt may come into contact with many chemicals generated from road traffic during use of the pavement: vehicle exhaust, gasoline, lubricating oils, and metals from tyres and brake lining wear. The major chemicals typically investigated in relation to asphalt pavement are heavy metals ( $\mathrm{Cd}, \mathrm{Cr}, \mathrm{Cu}, \mathrm{Ni}, \mathrm{Pb}$, and $\mathrm{Zn}$ ) and polycyclic aromatic hydrocarbons $(\mathrm{PAHs})^{(30)}$. Moreover, zinc and cadmium are produced mainly from tyre wear and the corrosion of galvanized steel crash barriers, and brake lining wear constitutes a source of copper ${ }^{(18)}$ the heavy metal contamination of highway runoff water and roadside soils was reported by other studies. ${ }^{(31,32)}$ 


\section{2-Around the proposed discharged points:}

\section{Physico-chemical characterization:}

As presented in table (6) total suspended solids are still higher than the permissible limits but it is lower than the samples around the discharges points. Suspended solids here may be due to the dewatering activities during the construction which are disposed to the sea directly. This proved that there is non point source. The others characterization are complying with the limits.

Generally, most parameters were detected in lower values than values detected in samples around the discharges points. Turbidity, COD, and oil and grease are higher which also indicate presence of non-point source. Oil and grease may be due to the fishing boats activities.

There is depletion of DO more than in samples around discharge points which indicate the presence of oxygen depleting compounds deposited from the high values of oil and grease and suspend ded solids.

\section{Toxic and persistent chemicals:}

Phenol was detected in mean value of $19.3 \mathrm{ppb}$, as presented in table (6), which un-complies with the limits and higher than values of samples around discharges. This was attributed to the urbanization in these areas.

PCBs were detected in mean value of $0.0004 \mathrm{ppb}$ and PAHs mean value of 0.434 ppm. These values are far below the values recorded in samples around discharges. This may be due to the decrease in suspended solids detected and also the slowly release of such compound to the water from the soils and sediments which they are bound by them. As contributed to the TPHs as presented in table (6), the mean value was $2.737 \mathrm{ppb}$ and complies with the limits. Also the maximum value was higher than the limits but lower than detected in samples around discharges. Generally these results indicated that the discharges are the main source of the input of such contaminant to 
the marine environment.

\section{Metals}

According to the limits presented by Qatari law, all metals detected mean values complying with the law except for iron, copper, and cadmium which detected mean values of $110 \mathrm{ppb}, 91 \mathrm{ppb}$, and $446 \mathrm{ppb}$, respectively, as presented in table (7). This is again resulting from the new roads construction and maintenance. Heavy metals including lead, copper, cadmium, Zinc, mercury, and chromium come from many sources: industrial activates and waste, illicit sewage connections, automobile wear exhaust and fluid leaks, and atmospheric deposition. These metals increase the toxicity of runoff and availability of metals that can enter into the food chain. Consequently, they accumulated in certain animal tissues that could be ingested by humans or other animals. ${ }^{(6)} \quad$ In comparison with the samples collected from sites around the discharges points; Magnesium, Beryllium, Chromium, Copper, Zinc, and Cadmium were higher. This may be due to the urbanization and new constructions projects near these points.

\section{2-Offshore reference point:}

\section{Physico-chemical characterization:}

Samples were collected from offshore sites to take it as references points. As represented in table (8), total suspended solids were slightly higher than the limits. It was noticed that inshore marine samples salinity were close to offshore samples which indicate that the discharged water did not change the marine ecology. Offshore sites detected the highest values of the oil and grease, $10.45 \mathrm{ppm}$, and total chloride, 27139.5 ppm in comparison with the shore sites. This could be attributed to the low dilution factors for the offshore points and the increase of the boats activities.

\section{Toxic and persistent chemicals:}

Phenol compounds are physic-chemical degradation by-products of many chemicals used in off-shore digging activities and oils discharged from ships engines cooling water. Their values are not complying with the law limits as their detected values were high with a mean value of $31.9 \mathrm{ppb}$. This can also be attributed to their low biodegradability. PCBs 
were detected mean value of $0.0005 \mathrm{ppb}$ and TPHs mean value of $0.064 \mathrm{ppb}$. TPHs were far below the permissible limits as represented in table ${ }^{(8)}$.

\section{Metals}

Metals measurements results, as presented in table (9), revealed that iron and copper are still higher than the limits and detected highest values. Iron mean value was $199.5 \mathrm{ppb}$ and copper mean value was 150.2 ppb. Katz and Rosen ${ }^{(33)}$ in their study reported that both copper and zinc concentrations were predictive of toxicity.

It was noticed that these offshore samples detected highest values of some metals: calcium (1991.5 ppm), Beryllium (246.2 $\mathrm{ppb})$, cobalt (0.82 ppb), Nickel (4.5 ppb), and selenium (69.2 ppb).This was due to the digging activities for gas.

\section{3-Sea water microbiological characterization:}

\section{Indicator organisms:}

The public health impacts of microbial contaminants are often a particular concern. Studies have identified potential links between storms and the outbreak of waterborne disease in human populations ${ }^{(34,35)}$.

Results recorded that as shown in figure (2), all indicator organisms examined were detected in highest values in the samples collected from sites around discharges points. This is related to the discharges itself. Total coliform was the highest one with mean MPN value of $5.62 \mathrm{E}+03 / 100 \mathrm{ml}$ followed by fecal streptococci with mean MPN value of $1.36 \mathrm{E}+03 / 100 \mathrm{ml}$ and finally fecal coliform with mean MPN value of $1.86 \mathrm{E}+02 / 100 \mathrm{ml}$. No limits were reported by Qatari law concerning the indicator organisms in sea water quality. Storm events and the resulting runoff generally account for a disproportionate fraction of total microbial loading to many receiving waters ${ }^{(36)}$.

Samples collected around the proposed points showed that fecal streptococci were the highest indicator, as shown in figure (2), with mean MPN value of $2.67 \mathrm{E}+02 / 100 \mathrm{ml}$. On the other hand, no fecal coliform was detected in reference samples. While total coliform value(6.35 MPN/100 ml) was higher than fecal streptococci (1.8 MPN/100 ml). 
Microbes associated with particles, particularly denser inorganic particles, will tend to settle out of the water column more quickly, while free phase organisms or those associated with less dense particles will remain more mobile in the marine environment. It has also been observed that microbes associated with particles tend to survive longer in natural waters ${ }^{(37)}$. Tidal water action can influence fecal indicator bacteria regrowth and its remobilization from sand leading to erroneous water quality postings ${ }^{(38)}$

Generally, as shown in figure (2), fecal streptococci are higher than fecal coliform in all sites. Faecal streptococci (which were termed "enterococci" survived longer in sea water than coliforms and E. coli. The Enterococcus organism may be the best indicator of recent pollution in sea water. Coliforms are sensitive to salinity, surviving more poorly in sea water (T90 of $2.2 \mathrm{~h}$ ) compared to fresh water. However, the phenomenon of superior survival of streptococci in sea water may, in part, be the result of superior resistance to sunlight. The authors concluded that faecal streptococci would make the most accurate indicators in sea water containing organic material since they do not multiply in such water and they show appreciable die-off rates within a 2-3day period".(10) $E$. coli survival in marine water was $0.8 \mathrm{~d}$ while enterococci survival was 2.4 d. E. coli degraded more rapidly with increased sunlight intensity than did enterococci. ${ }^{(39)}$

\section{Phytoplankton and Zooplankton:}

Phytoplankton and zooplankton were counted in sea water samples collected from sites around the discharges and from offshore sites as reference sites. Results, as shown in figure (3), indicated higher count for both around discharges than offshore samples. Samples around discharges sites recorded phytoplankton and zooplankton mean values of $1.05 \mathrm{E}+03$ cells/l and $3.6 \mathrm{E}+03$ cells/l, respectively. On the other hand, offshore samples recorded phytoplankton and zooplankton mean values of $5.0 \mathrm{E}+02$ cells/l and $6.0 \mathrm{E}+01$ cells/l, respectively. 
Direct and interactive effects of available solar radiation, and total phosphorus concentrations were found to be the best predictors of phytoplankton populations. ${ }^{(40)}$ Results revealed that the total phosphorus was higher in samples around discharges than in offshore samples.

Phytoplankton far from being negatively affected by the level of $\mathrm{NH}_{3}<2.5 \mathrm{mg} / \mathrm{l}$. it appear to be the main factor responsible for its increase. An intense photosynthetic activity and high related $\mathrm{pH}$, leads to a decrease in zooplankton biomass. ${ }^{(41)}$ Results reported $\mathrm{NH}_{3}<2.5 \mathrm{mg} / \mathrm{l}$ for both sites.

Phytoplankton primary production was not affected by $\mathrm{N}_{3}$ enrichment up to $1 \mathrm{mg}$ of $\mathrm{N}$ per liter. $\mathrm{NO}_{3}{ }^{-}$uptake is directly dependent on or related to electron transport to produce photoreductant. ${ }^{(42)}$ Results reported $\mathrm{NO}_{3}-\mathrm{N}$ $<1.0 \mathrm{mg} / \mathrm{l}$ for both sites. Relatively low levels of PCB can adversely affect certain physiological functions of algae in nature. Perhaps the most important impact was the marked reduction in biomass of all size classes for several days, an effect that might influence the availability of food for grazers $\left(10^{\prime} 23\right)$ in a complete plankton community. ${ }^{(43)}$ This can explain the generally low count recorded in samples.

\section{CONCLUSIONS AND RECOMMENDATIONS}

Suspended solids are the major highest parameter in all samples of discharges to marine water. Consequently, the other pollutant may adhere with it and exceeds their values. Qatar must proceed with an integrated management plan for the groundwater. All governmental and non-governmental authorities should be committed to participate in the plan covering the following items:

- Primary Treatment of the groundwater before it's discharged to the sea to minimize the amount of suspended and settleable solids with their burden of microorganisms.

- The use of advanced technology for sweeping streets to confirm the removal of all small particulates which carry out the microbes and adsorbed pollutants.

- Increase greening and landscaping to decrease the surface runoff.

- Monitoring of the dewatering activities of new constructions through construction permit.

- Monitoring the illegal discharge of tankers carrying industrial and septic tanks wastes. 
- Monitoring to the quality of the discharged water.

- Sewage sewers system must cover all the urban areas as planned in the near future.

- Qatar climate characterized by long period of sandy wind, so cultivation and maintaining a green belt surrounding the state can reduce its adverse effects on the environment.

- The environmental laws must report limits for fecal indicators in marine water.

\section{Acknowledgment}

Authors would like to thank all the participates of the project from public workers authorities and Qatar university, state of Qatar.

\section{Table (1): The different Physico-chemical and microbiological analytical methods used in the study}

\begin{tabular}{|c|c|c|c|}
\hline No. & Parameter & $\begin{array}{c}\text { Analytical Methods } \\
\text { number and reference }\end{array}$ & Technique \\
\hline 1 & $\begin{array}{c}\mathrm{pH} \text {, Temperature, Salinity, Conductivity, and } \\
\text { Turbidity }\end{array}$ & $\begin{array}{l}\text { Calibrated according to } \\
\text { manufacture instruction }\end{array}$ & YSI 6820 \\
\hline 2 & DO & SM-4500-O ${ }^{(6)}$ & Titration \\
\hline 3 & $\begin{array}{c}\text { Total Residual Chlorine/Free Chlorine, and } \\
\text { COD }\end{array}$ & $\mathrm{HACH}$ & Spectrometry \\
\hline 4 & TSS/TDS & SM-2540(6) & Gravimetric \\
\hline 5 & $\mathrm{BOD}_{5}$ & SM-5210-B ${ }^{(6)}$ & Membrane Electrode \\
\hline 6 & TOC & USEPA 415.1 $1^{(7)}$ & $\mathrm{C} / \mathrm{N}$ analyzer \\
\hline 7 & Alkalinity & SM-2320-B ${ }^{(6)}$ & Titration \\
\hline 8 & Total Chloride & $\mathrm{SM}-4500-\mathrm{Cl}^{(6)}$ & Titration \\
\hline 9 & Sulfide & UNEP, 1991, No. $50^{(8)}$ & Spectrometry \\
\hline 10 & Sulfate & SM-4500-SO4-2 - ${ }^{(6)}$ & Gravimetric \\
\hline 11 & Nitrate-Nitrogen & USEPA $353.3^{(7)}$ & Spectrometry \\
\hline 12 & Nitrite-Nitrogen & USEPA $354.1^{(7)}$ & Spectrometry \\
\hline 13 & Ammonia-Nitrogen & Reference ${ }^{(9)}$ & Spectrometry \\
\hline 14 & Phosphate & USEPA $365.2^{(7)}$ & Spectrometry \\
\hline 15 & Phenols & SM-5530(6) & Spectrometry \\
\hline 16 & Oil and Grease & USEPA $1664^{(7)}$ & Gravimetric \\
\hline 17 & PAHs & USEPA 8270(7) & GC-MS \\
\hline 18 & TPHs & USEPA $8015 b^{(7)}$ & GC-FID \\
\hline 19 & Metals & USEPA $200.8^{(7)}$ & $\mathrm{ICP} / \mathrm{MS}$ \\
\hline 20 & Mercury & USEPA $245.2^{(7)}$ & CVAAS \\
\hline 21 & PCBs & USEPA $8082^{(7)}$ & GC-ECD \\
\hline 22 & Total coliform & SM- 9221B ${ }^{(6)}$ & Tube Fermentation \\
\hline 23 & Fecal coliform & SM- 9221E ${ }^{(6)}$ & Tube Fermentation \\
\hline 24 & Fecal streptococci & SM- 9230B ${ }^{(6)}$ & Tube Fermentation \\
\hline 25 & Phytoplankton & SM- 10200C, $\mathrm{F}^{(6)}$ & Concentration and counting \\
\hline 26 & Zooplankton & SM- $10200 C, G^{(6)}$ & Concentration and counting \\
\hline
\end{tabular}


Table (2): Physico-chemical characterizations and persistence and toxic chemicals for water samples collected from discharge points

\begin{tabular}{|c|c|c|c|c|c|}
\hline \multirow{2}{*}{ Parameter (ppm) } & \multirow{2}{*}{ Mean } & \multirow{2}{*}{ Max. } & \multirow{2}{*}{ Min. } & \multicolumn{2}{|l|}{ Limits } \\
\hline & & & & Qatar & GCC \\
\hline Temperature $\left({ }^{\circ} \mathrm{C}\right)$ & - & 30 & 24 & $\begin{array}{c}\text { Not to exceed } 3 \\
\text { degrees above the } \\
\text { prevailing temperature }\end{array}$ & $\begin{array}{l}10^{\circ} \mathrm{C} \text { above } \\
\text { the ambient } \\
\text { temperature }\end{array}$ \\
\hline Conductivity $(\mathrm{mS} / \mathrm{cm})$ & 22.8 & 61.6 & 4.7 & - & - \\
\hline DO & 7.0 & 7.9 & 6.1 & - & - \\
\hline $\mathrm{pH}$ & - & 8.23 & 8.03 & 6 & 9 \\
\hline Turbidity (NTU) & 94.3 & 301 & 13.8 & 50 & $50-75$ \\
\hline Total Suspended Solids & 2475.2 & 20950.0 & 25.2 & 50 & $15-50$ \\
\hline Total Dissolved Solids & 19653.1 & 44674 & 3954 & 1500 & 1500 \\
\hline COD & 47.8 & 149.8 & 0.0 & 100 & $100-250$ \\
\hline BOD & 1.3 & 1.8 & 0.12 & 50 & $20-50$ \\
\hline Total Organic Carbon & 52.3 & 248 & 6.02 & - & 75 \\
\hline Oil and Grease & 1.6 & 10.1 & 0.0 & 15 & $10-15$ \\
\hline Total Alkalinity & 158.7 & 198 & 75.1 & - & - \\
\hline Ammonia-N $\left(\mathrm{NH}_{3}\right)$ & 0.4 & 2.5 & 0.002 & 3 & $1-3$ \\
\hline Nitrate-N $\left(\mathrm{NO}_{3}^{-}\right)$ & 1.9 & 6.5 & 0.3 & - & - \\
\hline Nitrite-N $\left(\mathrm{NO}_{2}^{-}\right)$ & 0.1 & 0.2 & 0.002 & - & - \\
\hline Total Kjeldahl Nitrogen & 0.1 & 0.5 & 0 & 10.0 & 5.0 \\
\hline Dissolved Inorganic Phosphorus & 0.1 & 0.7 & 0 & 2.0 & $2.0-5.0$ \\
\hline Total Chloride & 9227.9 & 24192 & 1303 & -- & - \\
\hline Sulfide & 0.1 & 0.4 & 0 & 0.1 & $0.1-0.5$ \\
\hline Sulfate & 4360.3 & 11447 & 1632 & - & - \\
\hline TPAHs (ppm) & 0.00055 & 0.00065 & 0.00049 & 0.1 & $0.001-0.2$ \\
\hline TPHs (ppb) & 9.16 & 22.44 & 0.05 & - & - \\
\hline PCBs (ppb) & 0.01 & 0.01 & 0.001 & - & - \\
\hline Phenol (ppm) & 0.008 & 0.018 & 0 & 0.5 & $0.002-5$ \\
\hline
\end{tabular}

Table (3): Metals concentrations in water samples collected from discharges

\begin{tabular}{|l|c|c|c|c|c|}
\hline \multirow{2}{*}{ Parameter(ppm) } & \multirow{2}{*}{ Mean } & \multirow{2}{*}{ Max. } & \multirow{2}{*}{ Min. } & \multicolumn{2}{|c|}{ Limits } \\
\cline { 5 - 6 } & & & & Qatar & GCC \\
\hline Magnesium (Mg) & 581.3 & 1292 & 63 & - & - \\
\hline Calcium (Ca) & 1383 & 5031 & 140 & - & - \\
\hline Mercury (Hg) & 0.0002 & 0.0001 & 0.00002 & 0.001 & $0.001-0.005$ \\
\hline Beryllium (Be) & 0.0004 & 0.0005 & 0.000002 & - & - \\
\hline Aluminium (Al) & 0.153 & 0.636 & 0.0046 & 3.0 & $3-25$ \\
\hline Chromium (Cr) & 0.052 & 0.172 & 0.005 & 0.2 & $0.1-0.5$ \\
\hline Manganese (Mn) & 0.015 & 0.060 & 0.00049 & 0.2 & $0.2-1$ \\
\hline Iron (Fe) & 0.066 & 0.0334 & 0.00014 & 1.0 & $1.5-10.0$ \\
\hline Cobalt (Co) & 0.0009 & 0.001 & 0.00049 & 2.0 & $0.5-2.0$ \\
\hline Nickel (Ni) & 0.008 & 0.013 & 0.004 & 0.5 & $0.1-2$ \\
\hline Copper (Cu) & 0.036 & 0.113 & 0.00049 & 0.5 & $0.2-1.5$ \\
\hline Zinc (Zn) & 0.008 & 0.032 & 0.00049 & 2.0 & $0.1-2$ \\
\hline Arsenic (As) & 0.007 & 0.015 & 0.00049 & 0.5 & 0.1 \\
\hline Selenium (Se) & 0.099 & 0.460 & 0.00049 & 0.02 & 0.02 \\
\hline Silver (Ag) & 0.0007 & 0.004 & 0 & 0.005 & $0.005-0.1$ \\
\hline Cadmium (Cd) & 0.191 & 0.621 & 0.00049 & 0.05 & $0.01-0.2$ \\
\hline Antimony (Sb) & 0.0007 & 0.002 & 0 & - & - \\
\hline Barium (Ba) & 0.032 & 0.058 & 0.009 & 2.0 & 2.0 \\
\hline Lead (Pb) & 0.007 & 0.041 & 0.0001 & 0.1 & $0.08-5$ \\
\hline
\end{tabular}


Table (4): Physico-chemical characterizations and persistence and toxic chemicals for marine water samples collected from points around discharges

\begin{tabular}{|c|c|c|c|c|}
\hline Parameter (ppm) & Mean & Max. & Min. & Qatar Limits \\
\hline Temperature $\left({ }^{\circ} \mathrm{C}\right)$ & - & 30.5 & 17.1 & - \\
\hline Conductivity $(\mathrm{mS} / \mathrm{cm})$ & 57.85 & 63.45 & 45.23 & - \\
\hline Salinity (PSU) & 39.83 & 42.66 & 32.19 & 33-45 (PSU) \\
\hline DO & 6.73 & 10.09 & 5.55 & $>4(\mathrm{ppm})$ \\
\hline DO\% & 106.13 & 132.7 & 89.6 & - \\
\hline $\mathrm{pH}$ & - & 8.49 & 7.42 & $6.5-8.3$ \\
\hline Turbidity (NTU) & 56.53 & 207 & 0.11 & - \\
\hline Free chlorine & 0.20 & 1.02 & 0.02 & - \\
\hline Total chlorine residual & 0.16 & 0.51 & 0.01 & - \\
\hline Total Suspended Solids & 76.49 & 429.91 & 15.33 & 30 (ppm) \\
\hline Total Dissolved Solids & 40105.38 & 48045 & 19099 & - \\
\hline COD & 39.56 & 110 & 0 & - \\
\hline BOD & 1.29 & 2.37 & 0.65 & - \\
\hline Total Organic Carbon & 25.90 & 178 & 9.17 & - \\
\hline Oil and Grease & 1.32 & 6.0 & 0 & - \\
\hline Total Alkalinity & 158.72 & 203 & 103 & - \\
\hline Ammonia- $\mathrm{N}\left(\mathrm{NH}_{3}\right)$ & 0.07 & 0.29 & 0.004 & $0.7(\mathrm{ppb})$ \\
\hline Nitrate-N $\left(\mathrm{NO}_{3}{ }^{-}\right)$ & 0.69 & 3.84 & 0.11 & $100(\mathrm{ppb})$ \\
\hline Nitrite-N $\left(\mathrm{NO}_{2}{ }^{-}\right)$ & 0.02 & 0.11 & 0.004 & $35(\mathrm{ppb})$ \\
\hline Total Kjeldahl Nitrogen & 0.37 & 1.39 & 0 & - \\
\hline Dissolved Inorganic Phosphorus & 0.05 & 0.92 & 0 & $30(\mathrm{ppb})$ \\
\hline Total Chloride & 21964.38 & 33529 & 9201 & - \\
\hline Sulfide & 0.03 & 0.15 & 0 & - \\
\hline Sulfate & 7776.65 & 38014 & 1222 & - \\
\hline TPAHs (ppb) & 22.15 & 39.59 & 0.386 & - \\
\hline TPHs (ppb) & 2.737 & 18.95 & 0.057 & $5(\mathrm{ppm})$ \\
\hline PCBs (ppb) & 30.39 & 549 & 0 & - \\
\hline Phenol (ppb) & 9.79 & 73.4 & 0 & Not to be presen \\
\hline
\end{tabular}

Table (5): Metals concentrations in marine water samples collected from points around discharges

\begin{tabular}{|l|c|c|c|c|}
\hline \multicolumn{1}{|c|}{ Parameter(ppb) } & Mean & Max. & Min. & Qatar Limits \\
\hline Magnesium (Mg) (ppm) & 1154.74 & 1748 & 9.09 & - \\
\hline Calcium (Ca) (ppm) & 2042.85 & 6296 & 0.31 & - \\
\hline Mercury (Hg) & 0.120 & 0.49 & 0.005 & $<0.4(\mathrm{ppb})$ \\
\hline Beryllium (Be) & 101.11 & 518 & 0.006 & - \\
\hline Aluminium (Al) & 1907.73 & 18297 & 0.49 & - \\
\hline Chromium (Cr) & 52.35 & 94 & 0.49 & - \\
\hline Manganese (Mn) & 12.99 & 311.97 & 0 & - \\
\hline Iron (Fe) & 134.733 & 12742 & 0 & $90(\mathrm{ppb})$ \\
\hline Cobalt (Co) & 1.403 & 6.03 & 0.36 & - \\
\hline Nickel (Ni) & 6.929 & 19.03 & 0.49 & $20(\mathrm{ppb})$ \\
\hline Copper (Cu) & 85.959 & 179.73 & 0 & $15(\mathrm{ppb})$ \\
\hline Zinc (Zn) & 26.298 & 250.2 & 0 & - \\
\hline Arsenic (As) & 121.997 & 2570 & 0.31 & - \\
\hline Selenium (Se) & 500.896 & 2655 & 0.89 & - \\
\hline Silver (Ag) & 74.925 & 1698 & 0.059 & - \\
\hline Cadmium (Cd) & 318.410 & 2228 & 0.49 & $0.7(\mathrm{ppb})$ \\
\hline Antimony (Sb) & 2.154 & 37.69 & 0 & - \\
\hline Barium (Ba) & 14.919 & 37.26 & 0.013 & - \\
\hline Lead (Pb) & 23.325 & 547 & 0 & $12(\mathrm{ppb})$ \\
\hline
\end{tabular}


Table (6): Physico-chemical characterizations and persistence and toxic chemicals for marine water samples collected from points around proposed sites

\begin{tabular}{|c|c|c|c|c|}
\hline Parameter (ppm) & Mean & Max. & Min. & Qatar Limits \\
\hline Temperature $\left({ }^{\circ} \mathrm{C}\right)$ & - & 30.1 & 16.7 & - \\
\hline Conductivity $(\mathrm{mS} / \mathrm{cm})$ & 61.5 & 63.9 & 52.7 & - \\
\hline Salinity (PSU) & 41.9 & 43.1 & 40.1 & 33-45 (PSU) \\
\hline DO & 6.4 & 10.4 & 4.6 & $>4(\mathrm{ppm})$ \\
\hline DO\% & 96.6 & 141 & 64.8 & - \\
\hline pH & - & 8.5 & 7.5 & $6.5-8.3$ \\
\hline Turbidity (NTU) & 61.3 & 511 & 0.3 & - \\
\hline Free chlorine & 0.05 & 0.15 & 0 & - \\
\hline Total chlorine residual & 0.152 & 0.33 & 0 & - \\
\hline Total Suspended Solids & 46.5 & 96.7 & 23.7 & $30(\mathrm{ppm})$ \\
\hline Total Dissolved Solids & 32114.5 & 57552 & 41.24 & - \\
\hline COD & 52.2 & 120 & 0 & - \\
\hline BOD & 1.3 & 2.2 & 0.9 & - \\
\hline Total Organic Carbon & 25.1 & 63.5 & 10.3 & - \\
\hline Oil and Grease & 7.1 & 35.6 & 0 & - \\
\hline Total Alkalinity & 145.8 & 178 & 77 & - \\
\hline Ammonia-N $\left(\mathrm{NH}_{3}\right)$ & 0.04 & 0.1 & 0.01 & $0.7(\mathrm{ppb})$ \\
\hline Nitrate-N $\left(\mathrm{NO}_{3}^{-}{ }^{-}\right)$ & 0.13 & 0.53 & 0.004 & $100(\mathrm{ppb})$ \\
\hline Nitrite- $\mathrm{N}\left(\mathrm{NO}_{2}^{-}\right)$ & 0.01 & 0.02 & 0 & 35 (ppb) \\
\hline Total Kjeldahl Nitrogen & 0.42 & 0.75 & 0 & - \\
\hline Dissolved Inorganic Phosphorus & 0.004 & 0.04 & 0 & $30(\mathrm{ppb})$ \\
\hline Total Chloride & 20818.7 & 33498 & 9834 & - \\
\hline Sulfide & 0.013 & 0.035 & 0 & - \\
\hline Sulfate & 4325.4 & 9668 & 2369 & - \\
\hline TPAHs (ppb) & 0.434 & 0.435 & 0.426 & - \\
\hline TPHs (ppb) & 1.848 & 12.3 & 0.056 & $5(\mathrm{ppm})$ \\
\hline PCBs (ppb) & 0.0004 & 0.0008 & 0 & - \\
\hline Phenol (ppb) & 19.3 & 80.4 & 0 & Not to be preser \\
\hline
\end{tabular}

Table (7): Metals concentrations in marine water samples collected from points around proposed sites

\begin{tabular}{|l|c|c|c|c|}
\hline \multicolumn{1}{|c|}{ Parameter(ppb) } & Mean & Max. & Min. & Qatar Limits \\
\hline Magnesium (Mg) (ppm) & 1326.9 & 1803 & 122 & - \\
\hline Calcium (Ca) (ppm) & 1323.4 & 3624 & 31 & - \\
\hline Mercury (Hg) & 0.093 & 0.4 & 0.009 & $<0.4(\mathrm{ppb})$ \\
\hline Beryllium (Be) & 148.7 & 518 & 0.002 & - \\
\hline Aluminium (Al) & 10.5 & 34.3 & 0.49 & - \\
\hline Chromium (Cr) & 95.8 & 237 & 5 & - \\
\hline Manganese (Mn) & 1.01 & 2.94 & 0 & - \\
\hline Iron (Fe) & 110.8 & 314 & 0 & $90(\mathrm{ppb})$ \\
\hline Cobalt (Co) & 0.73 & 1.25 & 0.49 & - \\
\hline Nickel (Ni) & 3.9 & 8.5 & 0.49 & $20(\mathrm{ppb})$ \\
\hline Copper (Cu) & 91.4 & 173.7 & 11.2 & $15(\mathrm{ppb})$ \\
\hline Zinc (Zn) & 144.7 & 1227 & 0.49 & - \\
\hline Arsenic (As) & 15.7 & 22 & 1.7 & - \\
\hline Selenium (Se) & 55.04 & 88.9 & 6.49 & - \\
\hline Silver (Ag) & 0.34 & 0.49 & 0.11 & - \\
\hline Cadmium (Cd) & 446.4 & 1979 & 0.49 & $0.7(\mathrm{ppb})$ \\
\hline Antimony (Sb) & 0.89 & 3.62 & 0 & - \\
\hline Barium (Ba) & 9.25 & 21.96 & 0.38 & - \\
\hline Lead (Pb) & 2.01 & 15.3 & 0 & $12(\mathrm{ppb})$ \\
\hline
\end{tabular}


Table (8): Physico-chemical characterizations and persistence and toxic chemicals for marine water samples collected from offshore points

\begin{tabular}{|c|c|c|c|c|}
\hline Parameter (ppm) & Mean & Max. & Min. & Qatar Limits \\
\hline Temperature $\left({ }^{\circ} \mathrm{C}\right)$ & - & 29 & 23 & - \\
\hline Conductivity (mS/cm) & 62.6 & 63.2 & 61.9 & - \\
\hline Salinity (PSU) & 41.6 & 41.6 & 41.6 & 33-45 (PSU) \\
\hline DO & 5.9 & 6.4 & 5.5 & $>4(\mathrm{ppm})$ \\
\hline $\mathrm{DO} \%$ & 89.4 & 89.4 & 89.4 & - \\
\hline $\mathrm{pH}$ & - & 8.5 & 8.3 & $6.5-8.3$ \\
\hline Turbidity (NTU) & 11.9 & 22.9 & 0.8 & - \\
\hline Free chlorine & ND & ND & ND & - \\
\hline Total chlorine residual & ND & ND & ND & - \\
\hline Total Suspended Solids & 36.9 & 37 & 36.8 & 30 (ppm) \\
\hline Total Dissolved Solids & 22018.6 & 43997 & 40.27 & - \\
\hline COD & 31.4 & 62.9 & 0 & - \\
\hline BOD & 0.76 & 1.33 & 0.19 & - \\
\hline Total Organic Carbon & 16.2 & 17.1 & 15.3 & - \\
\hline Oil and Grease & 10.45 & 20.9 & 0 & - \\
\hline Total Alkalinity & 145.5 & 149.9 & 141 & - \\
\hline Ammonia- $\mathrm{N}\left(\mathrm{NH}_{3}\right)$ & 0.25 & 0.49 & 0.01 & 0.7 (ppb) \\
\hline Nitrate- $\mathrm{N}\left(\mathrm{NO}_{3}{ }^{-}\right)$ & 0.027 & 0.027 & 0.007 & $100(\mathrm{ppb})$ \\
\hline Nitrite-N $\left(\mathrm{NO}_{2}^{-}\right)$ & 0.001 & 0.002 & 0 & $35(\mathrm{ppb})$ \\
\hline Total Kjeldahl Nitrogen & 0 & 0 & 0 & - \\
\hline Dissolved Inorganic Phosphorus & 0.005 & 0.01 & 0 & $30(\mathrm{ppb})$ \\
\hline Total Chloride & 27139.5 & 33290 & 20989 & - \\
\hline Sulfide & 0.017 & 0.02 & 0.014 & - \\
\hline Sulfate & 5083 & 5818 & 4348 & - \\
\hline Phenol (ppb) & 31.9 & 63.9 & 0 & Not to be present \\
\hline TPHs & 0.064 & 0.08 & 0.047 & $5(\mathrm{ppm})$ \\
\hline PCBs (ppb) & 0.0005 & 0.0009 & 0 & - \\
\hline
\end{tabular}

Table (9): Metals concentrations in marine water samples collected from offshore points

\begin{tabular}{|l|c|c|c|c|}
\hline Parameter(ppb) & Mean & Max. & Min. & $\begin{array}{c}\text { Qatar } \\
\text { Limits }\end{array}$ \\
\hline Magnesium (Mg) (ppm) & 1239.5 & 1344 & 1135 & - \\
\hline Calcium (Ca) (ppm) & 1991.5 & 3702 & 281 & - \\
\hline Mercury (Hg) & 0.012 & 0.014 & 0.01 & $<0.4(\mathrm{ppb})$ \\
\hline Beryllium (Be) & 246.2 & 492 & 0.49 & - \\
\hline Aluminium (Al) & 4.555 & 8.6 & 0.49 & - \\
\hline Chromium (Cr) & 55.2 & 63.4 & 47 & - \\
\hline Manganese (Mn) & 1.035 & 1.58 & 0.49 & - \\
\hline Iron (Fe) & 199.5 & 285 & 114 & $90(\mathrm{ppb})$ \\
\hline Cobalt (Co) & 0.82 & 1.15 & 0.49 & - \\
\hline Nickel (Ni) & 4.5 & 8.51 & 0.49 & $20(\mathrm{ppb})$ \\
\hline Copper (Cu) & 150.2 & 181.3 & 119 & $15(\mathrm{ppb})$ \\
\hline Zinc (Zn) & 88.4 & 176.3 & 0.49 & - \\
\hline Arsenic (As) & 12.2 & 15.6 & 8.8 & - \\
\hline Selenium (Se) & 69.2 & 78.9 & 59.5 & - \\
\hline Silver (Ag) & 0.28 & 0.49 & 0.07 & - \\
\hline Cadmium (Cd) & 0.49 & 0.49 & 0.49 & $0.7(\mathrm{ppb})$ \\
\hline Antimony (Sb) & 0.39 & 0.49 & 0.29 & - \\
\hline Barium (Ba) & 5.8 & 11.1 & 0.49 & - \\
\hline Lead (Pb) & 0.33 & 0.49 & 0.17 & $12(\mathrm{ppb})$ \\
\hline
\end{tabular}




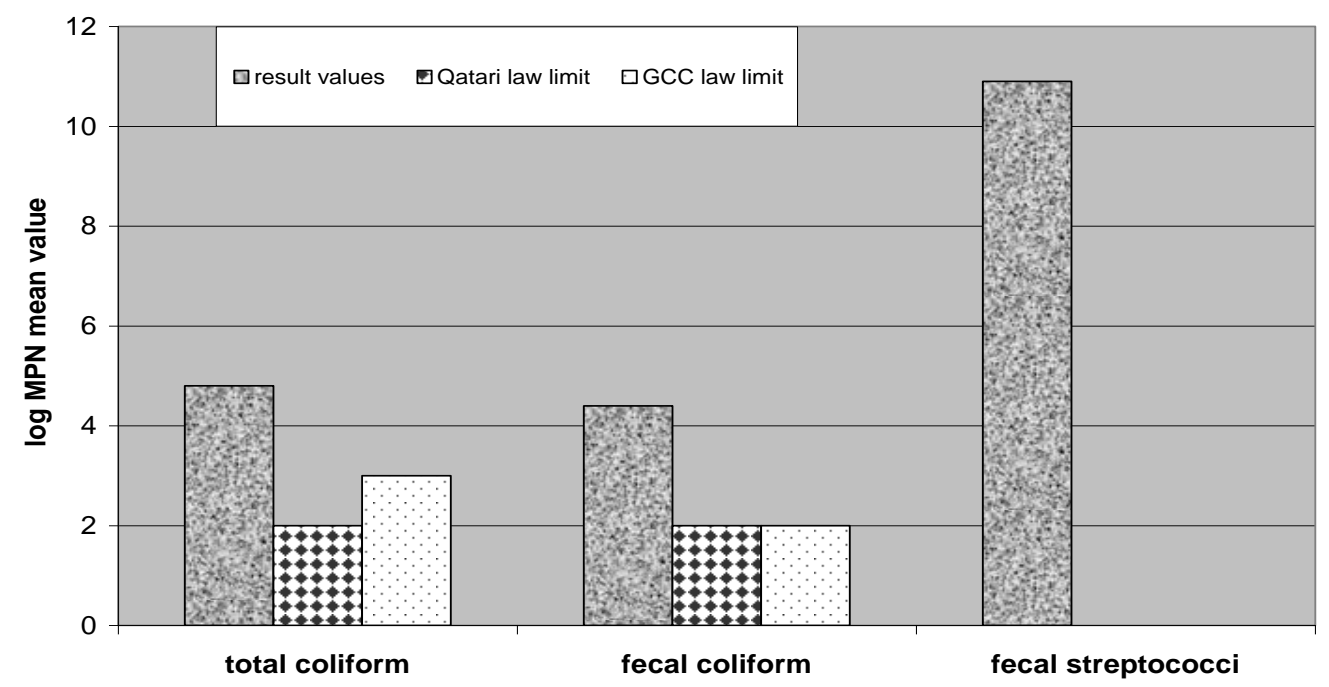

Figure (1): Fecal indicators detected in discharged water samples compared with the environmental laws

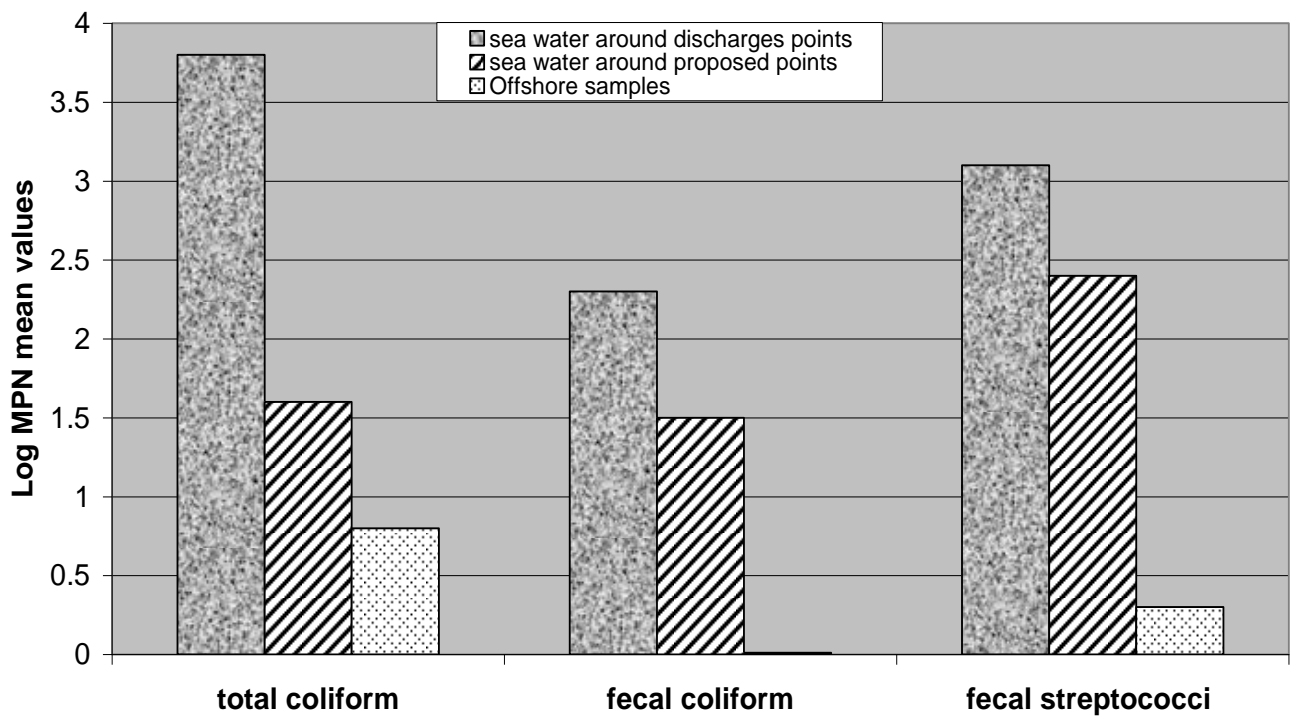

Figure(2):Fecal Indicators detected in sea water samples 


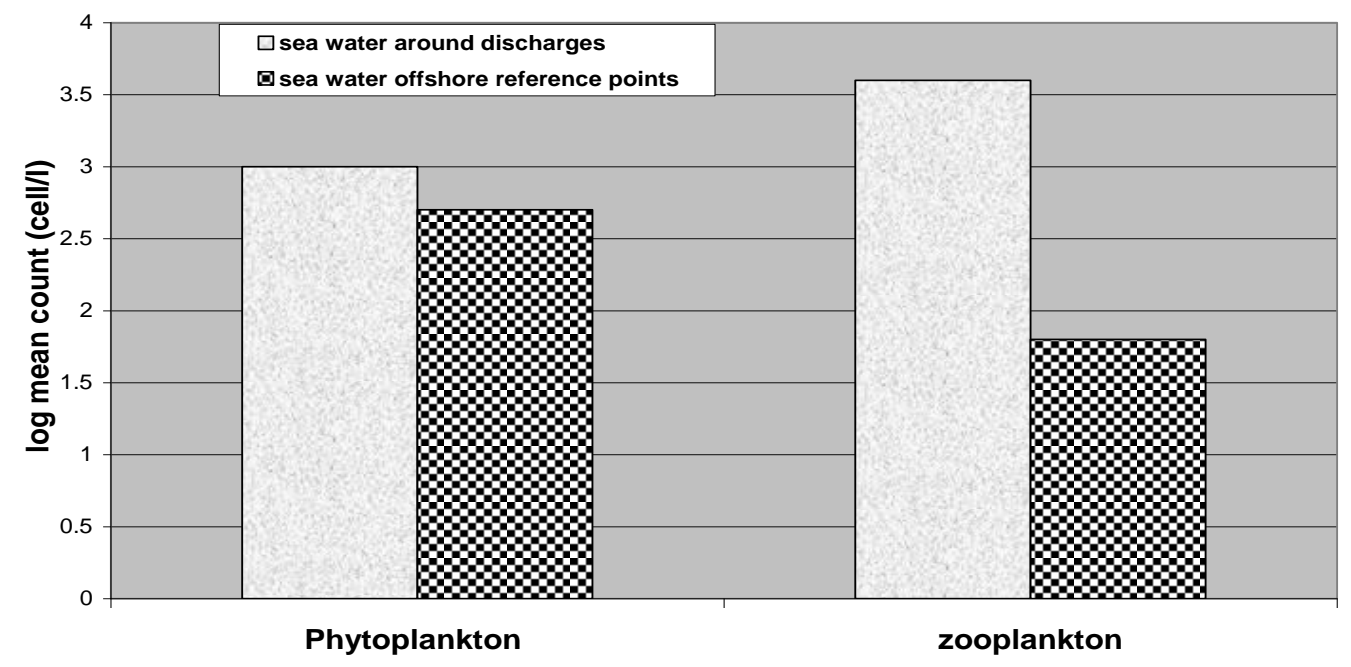

Figure(3): Phytoplankton and Zooplankton mean count in sea water samples collected from sites around discharges and offshore.

\section{REFERENCES}

1. United Nations Environmental Programme. Global Environmental Outlook-1. Global State of the Environmental report 1997, chapter 2 (Regional perspectives). Available from: $\quad$ http://www.unep.org/geo/ geo1/ch/ch2 13.htm

2. State of Qatar. Environment in Qatar. Available from: http://www.qatarembassy.net/environm ent.asp

3. Encyclopedia Article. Qatar. Available from:

http://encarta.msn.com/encyclopedia_7 61554212_2/qatar.html

4. Wikipedia, the free encyclopedia. Geography of Qatar. Available from: http://en.wikipedia.org/wiki/Geography_ of_Qatar

5. Storm Water Runoff and Its Impact. Available from: http://www.state.in.us/idem//stormwate/ docs/web files/chap1.pdf

6. Eaton $A D$, Clesceri LS, Greenberg AE. Standard Method for the Examination of Water and Wastewater. 19thed.Denver: APHA;1995.

7. USEPA. Methods of chemical analysis. EPA;1996.

8. UNEP. Standard chemical methods for marine environmental monitoring, R.M.No. 50. UNEP;1991.

9. Parsons R, Maita Y, Lalli CM. A Manual of Chemical and Biological Methods for Seawater Analysis. Pergamon Press; 1992.

10. Sinton W, Donnison AM, Hastie CM. Faecal streptococci as faecal pollution indicators: a review. Part II: Sanitary significance, Survival, and Use. New Zealand Journal of Marine and Freshwater Research. 1993; vol.27: 117-37. 
11. Stormwater. Technical and Issue

Papers Chapter 4: Environmental Assessment. Available from: http://www.epa.gov/npdes/pubs/usw_b. pdf

12. Bilotta GS, Brazier RE. Understanding the influence of suspended solids on water quality and aquatic biota. Available

www.sciencedirect.com. Journal homepage: www.elsevier.com/locate/watres .

13. Berbee R, Rijs G, de Brouwer R, van Velzen $L$. Characterization and treatment of runoff from highways in the Netherlands paved with impervious and pervious asphalt. Water Environ. Res. 1999; 71 (2): 183-90.

14. Wu JS, Allen CJ, Saunders WL, Evett JB. Characterization and pollutant loading estimation for highway runoff. J Environ Eng. 1998;124(7):584-92.

15. Pitt $R$, Field $R$, Lalor $M$, Brown $M$. Urban stormwater toxic pollutants: assessment, sources and treatability. Water Environ Res. 1995;67(3):260-75.

16. Environmental Protection Department, The Government of the Hong Kong. Water: marine water quality. Available from: $\quad$ http://www.epa.gov.hk/epd/ english/environmentinhk/water/marine quality/Dio fur.html.

17. Environmental Protection Division, Ministry of Environment. Government of British Columbia. Ambient water quality guidelines for phenol. Available from:http://www.env.gov.bc.ca/wat/wq/ BCguidelines/phenol/phenol.html

18. Legreta $M$, Odie L, Demare $D$, Jullien A. Leaching of heavy metals and polycyclic aromatic hydrocarbons from reclaimed asphalt pavement. Water Research. 2005: 3675-85.

19. Takada H, Tomodo O, Ogura N. Determination of polycyclic aromatic hydrocarbons in urban street dusts and their source material by capillary gas chromatography. Environ. Sci Technol. 1990;11:1179-86.

20. Baek SO, Field RA, Goldstone ME, Kirk PW, Lester JN, Perry R. A review of atmospheric polycyclic aromatic hydrocarbons: sources, fate and behaviour. Water Air Soil Pollut. 1991; 60:279-300.

21. Sadler R, Delamont C, White $P$, Connell D. Contaminants in soils as a result of leaching from asphalt. Toxicol Environ Chem. 1999;68;71-81.

22. Krein A, Schorer M. Road runoff pollution by polycyclic aromatic hydrocarbons and its contribution to river sediments. Wat Res. 2000;34(16):4110-5.

23. Faure $P$, Landais $P$, Schlepp $L$, Michels R. Evidence for diffuse contamination of river sediments by road asphalt particles. Environ Sci Technol. 2000;34:1174-81.

24. Murakami M, Nakajima F, Furumai $H$. Modelling of runoff behaviour of particle-bound polycyclic aromatic hydrocarbons (PAHs) from roads and roofs. Water Research. 2004:4475-83.

25. Hoffman EJ, Mills GL, Latimer JS, Quinn JG. Urban runoff as a source of polycyclic aromatic hydrocarbons to coastal waters. Environ Sci Technol. 1984; 18:580-7.

26. Mithlesh KC, Kadam AN, Zingde MD. Petroleum hydrocarbon residues in marine environment of BasseinMumbai. Marine Pollution Bulletine. 2004; 49(7-8):637-47.

27. Brattebo BO, Booth DB. Long-term stormwater quantity and quality performance of permeable pavement systems. Water Research. 2003; 4369-76.

28. Fondekar SP, Alagarsamy R. Petroleum hydrocarbon contamination along oil tanker routes in the Arabian 
sea. Indian Journal of Marine Science. 1984; 13: 181-3.

29. Mohan PC. Prakash RR. Concentration of petroleum hydrocarbons in bivalve Mytilopsis sallei and in the harbour waters of Visakhaptnam, East coast of India. Indian Journal of Marine Science. 1998; 27: 496-8.

30. Brantley AS, Townsend TG. Leaching of pollutants from reclaimed asphalt pavement. Environ Eng Sci. 1999; 16 (2): 105-16.

31. Pagotto $C$, Legret $M$, Le Cloirec $P$. Comparison of the hydraulic behaviour and the quality of highway runoff water according to the type of pavement. Water Res. 2000; 34 (18): 4446-54.

32. Pagotto $C, R e^{\prime}$ my $N$, Legret $M$, Le Cloirec P. Heavy metal pollution of road dust and roadside soil near a major rural highway. Environ Technol. 2001; 22: 307-19.

33. Katz CN, Rosen G. Evaluating Storm Water Impacts- Monitoring the Receiving Environment Using a Floating Bioassay Laboratory System. Available from:http://ieeexplore.ieee. org/iel5/10918/34367/01640002.pdf?tp $=$ \&isnumber $=$ \&arnumber $=1640002$

34. Currieo FC, Pataz AJ, Rose JB, Lele S. The association between extreme precipitation and waterborne disease outbreaks in the United States, 19481994. Am J Public Health. 2001;91(8): 1194-9.

35. Rose JB, Epstein PR, Lipp EK, Sherman $\mathrm{BH}$, Bernard SM, Patz JA. Climate variability and change in the United States: potential impacts of water- and food-borne diseases caused by microbiologic agents. Environ Health Perspectives. 2001;109(2):211-9.

36. Jamieson R. Gordon R, Joy D, Lee $\mathrm{H}$. Assessing microbial pollution of rural surface waters: a review of current watershed scale modeling approaches. Agric Water Manage. 2004;70:1-70.

37. Characklis GW, Dilts MJ, Simmons OD, Likirdopulos CA, Krometis LH, Sobsey MD. Microbial partitioning to settleable particles in stormwater. Water Research. 2005; 1773-82

38. Lee CM, Lin TY, Lin CC, Kohbodi GA, Bhatt $A$, Lee R, Jay JA. Persistence of fecal indicator bacteria in Santa Monica Bay Beach sediments. Water Research. 2006; $2593-602$

39. Noble RT, Moore DF, Leecaster MK, McGee CD, Weisberg SB. Comparison of total coliform, fecal coliform, and enterococcus bacterial indicator response for ocean recreational water quality testing. Water Research. 2003; 1637-43.

40. Arhonditsis GB, Winder M, Brett MT, Chandler DE. Patterns and mechanisms of phytoplankton variability in Lake Washington (USA). Water Research. 2004;4013-27.

41. Arauzo M. Harmful effects of unionised ammonia on the zooplankton community in a deep waste treatment pond. Water Research. 2003; 104854.

42. Chan YK, Campbell NER. Phytoplankton Uptake and Excretion of assimilated Nitrate in a Small Canadian Shield Lake. Applied and Environmental Microbiology. 1978; 35(6): 1052-60.

43. Donald Powers C., Rowland RG, O'connors HB, JR, Wurster CF. Response to Polychlorinated Biphenyls of Marine Phytoplankton Isolates Cultured Under Natural Conditions. Applied and Environmental Microbiology. 1977;34(6):760-4. 